\title{
The Use of Neuronavigation and Intraoperative Imaging Systems in the Surgical Treatment of Orbital Tumors
}

\author{
Orbita Tümörlerinin Cerrabi Tedavisinde Nöronavigasyon ve \\ Intraoperatif Görüntüleme Sistemlerinin Kullanımı
}

Irgen HODAJ, Murat KUTLAY, Engin GONUL, Ilker SOLMAZ, Ozkan TEHLI, Caglar TEMIZ, Cahit KURAL, Mehmet K. DANEYEMEZ, Yusuf IZCI

Gulbane Military Medical Academy, Department of Neurosurgery, Ankara, Turkey

Corresponding Author: Yusuf IZCI / E-mail: yusufizci@yahoo.com

\begin{abstract}
AIM: We aimed to show the effects of neuronavigation and intraoperative imaging systems on the surgical outcomes of orbital tumors.

MATERIAL and METHODS: Seventeen patients who underwent surgical treatment for orbital tumors by transcranial and transnasal approaches between 2008 and 2013 were analyzed retrospectively. Twelve of them were male and 5 were female. The mean age was 41.6 years. Neuronavigation systems were used in all cases. Four patients were operated using intraoperative imaging systems.

RESULTS: The transcranial approach was used in 9 (53\%) patients, endoscopic medial orbital approach in 4 (23.5\%), endoscopic inferolateral approach in 1 (6\%), cranioorbitozygomatic approach in 1, lateral approach in 1, and the combined (medial endoscopic and lateral) approach in 1 patients. Total resection was achieved in 5 patients, gross total excision in 2, subtotal in 9 and partial in 1 patients.

CONCLUSION: Modern technology has made a significant contribution to the treatment of orbital tumors. Although technological equipments facilitate the excision of tumors, the level of resection is mainly determined by the nature of tumor and adhesion to the adjacent neurovascular structures. It should not be forgotten that advanced technology never replaces a good anatomical knowledge and surgical experience, but has a complementary role.
\end{abstract}

KEYWORDS: Orbital tumor, Surgery, Endoscopy, Navigation, Intraoperative imaging

Öz

AMAÇ: Çalışmamızda orbita tümörlerinde intraoperatif görüntüleme ve nöronavigasyon sistemlerinin cerrahi sonuçlar üzerindeki etkilerini göstermeyi amaçladık.

YÖNTEM ve GEREÇLER: 2008-2013 yılları arasında kliniğimizde orbita tümörü tanısı almış, mikroskobik ve/veya endoskopik teknikler ile transkraniyal ve transnazal yaklaşımlar kullanılarak opere edilen 17 olgu retrospektif olarak incelenmiştir. Bu olguların 12 tanesi erkek, 5 tanesi kadın ve ortalama yaş 41,6 yıl idi. Tüm olgularda nöronavigasyon sistemi kullanılmış, olguların 3'ünde intraoperatif manyetik rezonans görüntüleme (MRG), 1'inde ise intraoperatif bilgisayarlı tomografi (BT) kullanılmıştır.

BULGULAR: Çalışmada 9 hastaya (\%53) transkraniyal yaklaşım, 4 hastaya $(\% 23,5)$ endoskopik endonazal medial orbital yaklaşım, 1 hastaya (\%6) inferolateral endoskopik yaklaşım, 1 hastaya kraniyo-orbitozigomatik yaklaşım, 1 hastaya lateral yaklaşım, 1 hastaya ise kombine (medial endoskopik+lateral) yaklaşım uygulandı. Beş hastada total, 2 hastada gros total, 9 hastada subtotal, 1 hastada ise parsiyel eksizyon yapılabilmiştir.

SONUÇ: Modern teknolojinin, orbita tümörlerinin cerrahi tedavisinde cerraha büyük katkıları vardır. Her ne kadar bu teknolojik olanaklar, bu bölge tümörlerinin eksizyonlarını kolaylaştırsa da, yine de tümörün çıkarılma oranını, tümörün natürü ve çevre nörovasküler yapılara olan yapışıklığının derecesi belirlemektedir. İleri teknolojinin hiç bir zaman iyi bir anatomik bilgi ve deneyimin yerini tutamayacağı, ancak bunların tamamlayıcı konumda olabileceği unutulmamalıdır.

ANAHTAR SÖZCÜKLER: Orbita tümörü, Cerrahi, Endoskopi, Navigasyon, İntraoperatif görüntüleme

\section{INTRODUCTION}

The orbit has been an area of interest among neurosurgeons and ophthalmologists since ancient times. The orbit comprises important organs and neurovascular structures related to visual functions such as the eyeball and optic nerve (10). The borders of the orbit are mainly bones except the anterior border. All of the structures in the orbit work in coordination for eye movements and visual functions.

Most of the lesions found in the orbit during antiquity were orbital traumas associated with head traumas. The first orbital 
approach by preserving the orbit was performed by Thomas Hope in 1744. Krönlein was the first surgeon to describe the lateral approach in 1888 for retrobulbar orbital tumors (15). Dandy used the transcranial approach in 1941 (4). Davis described the anteroinferior approach that was performed by an inferior orbital incision (5).

The options for the treatment of orbital lesions have increased in the recent years by the development of diagnostic methods, operative techniques, surgical instruments and equipment (microscope, endoscope, microsurgical tools) $(11,22)$.

Currently, 2 main operative techniques are in use for the surgical treatment of orbital tumors: the transcranial approach and transnasal approach. Transcranial approaches are performed by superior orbitotomy, lateral orbitotomy, medial orbitotomy, inferior orbitotomy, inferomedial orbitotomy and inferolateral orbitotomy. The main difference between these approaches is the wall of orbit that is used to access the lesion. There are several anatomical ways to reach an intraorbital lesion. One of the above approaches is selected according to the location of the lesion and the surgical treatment is performed by this technique.

The transnasal approach is used for the removal of medial or inferomedial orbital lesions by the nasal corridor. This approach may be performed either by a microscope or endoscope. In recent years, endoscopic transnasal approaches have become popular for the removal of orbital lesions. Transcranial approaches are mainly performed under a microscope but these approaches can also be performed with endoscope-assisted techniques. The endoscopic technique has some advantages such as panoramic view of the lesion from different angles and clear exposure of the deep-seated lesions. However, the 2-dimensional image and the long-learning curve are disadvantages of the endoscopic technique. These disadvantages will disappear in the next few years by the development of 3-dimensional endoscopes and increased experience of the surgeons (3).

In addition to endoscopes, neuronavigation systems and intraoperative imaging techniques have become available worldwide in recent years and are in use in most neurosurgical departments. These developments also facilitate the removal of orbital lesions and help neurosurgeons for a safe and effective surgery $(17,23)$. In our department, endoscope was first used for intracranial lesions and hydrocephalus in 2002 and then navigation systems and intraoperative imaging instruments (ultrasound, computed-tomography (CT), and magnetic resonance imaging (MRI)) have become available since 2008 for cranial and spinal lesions.

In this study, we retrospectively analyzed the surgical results of 17 cases that underwent surgical treatment for an orbital tumor in the last 5 years. The clinical, radiological and surgical characteristics of these cases were documented. Our aim was to reveal the contribution and effects of modern technological equipment on the surgical outcome of orbital tumors and to compare our results with the current literature.

\section{MATERIAL and METHODS}

Seventeen patients who underwent surgical treatment in our department for an orbital tumor between 2008 and 2013 were included in this study. The informed consent form was signed by all patients before the surgical treatment. All patients and their relatives were informed of the risks, benefits, outcomes and complications of surgery.

Detailed neurological and ophthalmological examinations were performed in all patients. Fundoscopic examination and visual field tests were performed by an ophthalmologist before and after surgery. MRI and/or CT scans with 160-200 slices were obtained preoperatively for the set-up of the navigation system.

A neuronavigation system (Stealth station ${ }^{\circledR}$, Medtronic Surgical Navigation Technologies, Louisvile, USA) was used in all cases during the surgery. A microscope (OPMI Pentero ${ }^{\circledR}$-Carl Zeiss Meditec AG, Germany) was used in 12 cases, an endoscope (Karl Storz, CA, USA) in 6 cases, and both the microscope and endoscope in 1 case. Microsurgical instruments were used in both microscopic and endoscopic techniques. In addition, intraoperative magnetic resonance imaging (iMRI) (PoleStar $\mathrm{N} 20^{\circledR}$, Medtronic, Louisville, USA) was used in 3 (17.6\%) cases (Figure 1) and intraoperative computed tomography (iCT) $\left(\mathrm{O}-\right.$ arm $^{\circledast}$, Medtronic, Louisville, USA) in 1 case who had orbital osteoma.

Initially, the head of the patient was fixed with the 3-pin head holder. The navigation system was set-up with appropriate $\mathrm{MRI}$ and/or CT scans according to the navigation protocol. A passive cranial frame was fixed to the 3-pin head holder and the system was checked after the set-up. The MRI-based neuronavigation system was used in 16 (94\%) patients and the CT-based navigation system was used in 1 patient with osteoma.

The surgical approach was selected for each patient according to the location of the tumor. The transcranial approach was used in 9 (53\%) patients, the medial endoscopic orbital approach (M-EOA) in $4(23.5 \%)$ patients, the inferolateral endoscopic approach (IL-EOA) in 1 (6\%) patient, the cranioorbitozygomatic approach (COZ) in 1 patient, the lateral approach in 1 patient, and the combined approach (M-EOA and lateral) in 1 patient. Documentation of the patients based on surgical approach is shown in Table I.

As the target anatomical area (orbit) was a quite small and contained important neurovascular structures, particular attention was paid to hemostasis during the dissection of tumor with microsurgical and endoscopic techniques. First, internal debulking of the tumor was performed with dedicated surgical instruments. Then, the other parts of the tumor were dissected and removed using blunt surgical instruments. Neuronavigation systems were used in all of stages of the surgery to check the location of important structures and tumor. The tumor parts that were very adherent to neurovascular tissues were left in place in 
Table I: Documentation of the Patients Based on Surgical Technique and Use of Navigation and Intraoperative Imaging Systems

\begin{tabular}{|c|c|c|c|c|c|}
\hline \multirow{2}{*}{ Patient No } & \multirow{2}{*}{ Surgical Approach } & \multicolumn{2}{|c|}{ Navigation } & \multirow{2}{*}{ Intraoperative MRI } & \multirow{2}{*}{ Intraoperative CT } \\
\hline & & MRI & CT & & \\
\hline 1 & $\mathrm{TC}$ & + & - & - & - \\
\hline 2 & İL-EOA & + & - & - & - \\
\hline 3 & $\mathrm{TC}$ & + & - & - & - \\
\hline 4 & $\mathrm{TC}$ & + & - & - & - \\
\hline 5 & $\mathrm{TC}$ & + & - & - & - \\
\hline 6 & M-EOA & - & + & - & + \\
\hline 7 & $\mathrm{TC}$ & + & - & - & - \\
\hline 8 & $\mathrm{TC}$ & + & - & - & - \\
\hline 9 & M-EOA & + & - & + & - \\
\hline 10 & $\mathrm{~L}$ & + & - & - & - \\
\hline 11 & $\mathrm{TC}$ & + & - & - & - \\
\hline 12 & M-EOA & + & - & + & - \\
\hline 13 & $\mathrm{TC}$ & + & - & - & - \\
\hline 14 & $\mathrm{TC}$ & + & - & + & - \\
\hline 15 & M-EOA + L & + & - & - & - \\
\hline 16 & $\mathrm{COZ}$ & + & - & - & - \\
\hline 17 & M-EOA & + & - & - & - \\
\hline
\end{tabular}

TC: Transcranial, IL-EOA: Inferolateral-endoscopic orbital approach, M-EOA: Medial-endoscopic orbital approach, L: Lateral approach, COZ: Cranio-orbitozygomatic approach).

Table II: Documentation of the Patients Based on Age, Sex, Clinical Findings, Histological Diagnosis and Level of Excision

\begin{tabular}{|c|c|c|c|c|c|c|c|c|c|}
\hline \multirow{2}{*}{$\begin{array}{l}\text { Patient } \\
\text { No }\end{array}$} & \multirow[b]{2}{*}{ Age } & \multirow[b]{2}{*}{ Sex } & \multicolumn{5}{|c|}{ Clinical Findings } & \multirow{2}{*}{$\begin{array}{l}\text { Histological } \\
\text { Diagnosis }\end{array}$} & \multirow[b]{2}{*}{ Excision Level } \\
\hline & & & Proptosis & Pain & $\begin{array}{l}\text { Visual } \\
\text { Loss }\end{array}$ & $\begin{array}{l}\text { Limitation of Eye } \\
\text { Movements }\end{array}$ & Diplopia & & \\
\hline 1 & 59 & $M$ & - & - & + & - & - & Meningioma & Subtotal \\
\hline 2 & 27 & $\mathrm{~F}$ & - & - & - & - & - & Epidermoid cyst & Gross total \\
\hline 3 & 54 & $M$ & + & - & + & - & - & Meningioma & Subtotal \\
\hline 4 & 31 & M & + & + & - & - & - & Cavernoma & Total \\
\hline 5 & 57 & $M$ & + & + & + & + & - & Meningioma & Partial \\
\hline 6 & 43 & $M$ & - & + & - & - & - & Osteoma & Subtotal \\
\hline 7 & 20 & $M$ & + & - & - & - & - & $\begin{array}{l}\text { Mesenchymal } \\
\text { tumor }\end{array}$ & Subtotal \\
\hline 8 & 33 & $M$ & - & + & - & - & - & Lipoma & Subtotal \\
\hline 9 & 39 & $M$ & - & + & - & - & - & Epidermoid cyst & Gross total \\
\hline 10 & 57 & $M$ & + & - & + & - & - & Metastasis & Total \\
\hline 11 & 74 & $\mathrm{~F}$ & + & + & - & + & - & Meningioma & Subtotal \\
\hline 12 & 60 & $\mathrm{~F}$ & - & + & - & - & - & Epidermoid cyst & Total \\
\hline 13 & 5 & $M$ & - & - & - & - & - & $\begin{array}{l}\text { Eosinophilic } \\
\text { granuloma }\end{array}$ & Total \\
\hline 14 & 29 & $\mathrm{~F}$ & + & - & - & - & - & Fibroma & Total \\
\hline 15 & 20 & $M$ & - & + & - & - & - & Lymphangioma & Subtotal \\
\hline 16 & 66 & M & + & - & - & - & - & Lymphoma & Subtotal \\
\hline 17 & 34 & $\mathrm{~F}$ & + & - & - & - & + & Mucocele & Subtotal \\
\hline
\end{tabular}


order to prevent severe complications and to decrease the morbidity. No aggressive and invasive surgical manipulations were performed during the surgery. Subtotal and partial removal were performed in these cases after the confirmation of adequate decompression with iMRI and iCT.

All patients were transferred to the intensive care unit after surgery. They were followed by experienced nurses in this unit and possible complications such as loss of vision, diplopia, orbital swelling, and hemorrhage were checked by these nurses. Postoperative CT scan was performed in the first 24 hours after surgery in all the patients. These scans were evaluated for hemorrhage and other complications.

The level of excision was determined by the impression of the surgeon during the surgery and by the neuroradiological examination that was performed 3 months after surgery. The level of excision was classified as total (no surgical and radiological visible residual tumor), gross total (resection without visual residual tumor), subtotal (50\% to $90 \%$ tumor removal) and partial (less than 50\% tumor removal) excision.

The mean follow-up period was 16 months, ranging between 3 and 36 months. All patients were evaluated by clinical examination and MRI scans at the postoperative $3^{\text {rd }}, 6^{\text {th }}$ and $12^{\text {th }}$ month. After the first year, annual controls were performed for each patient. CT scans in the follow-up period were performed in patients who had solid or calcified tumors such as osteoma.

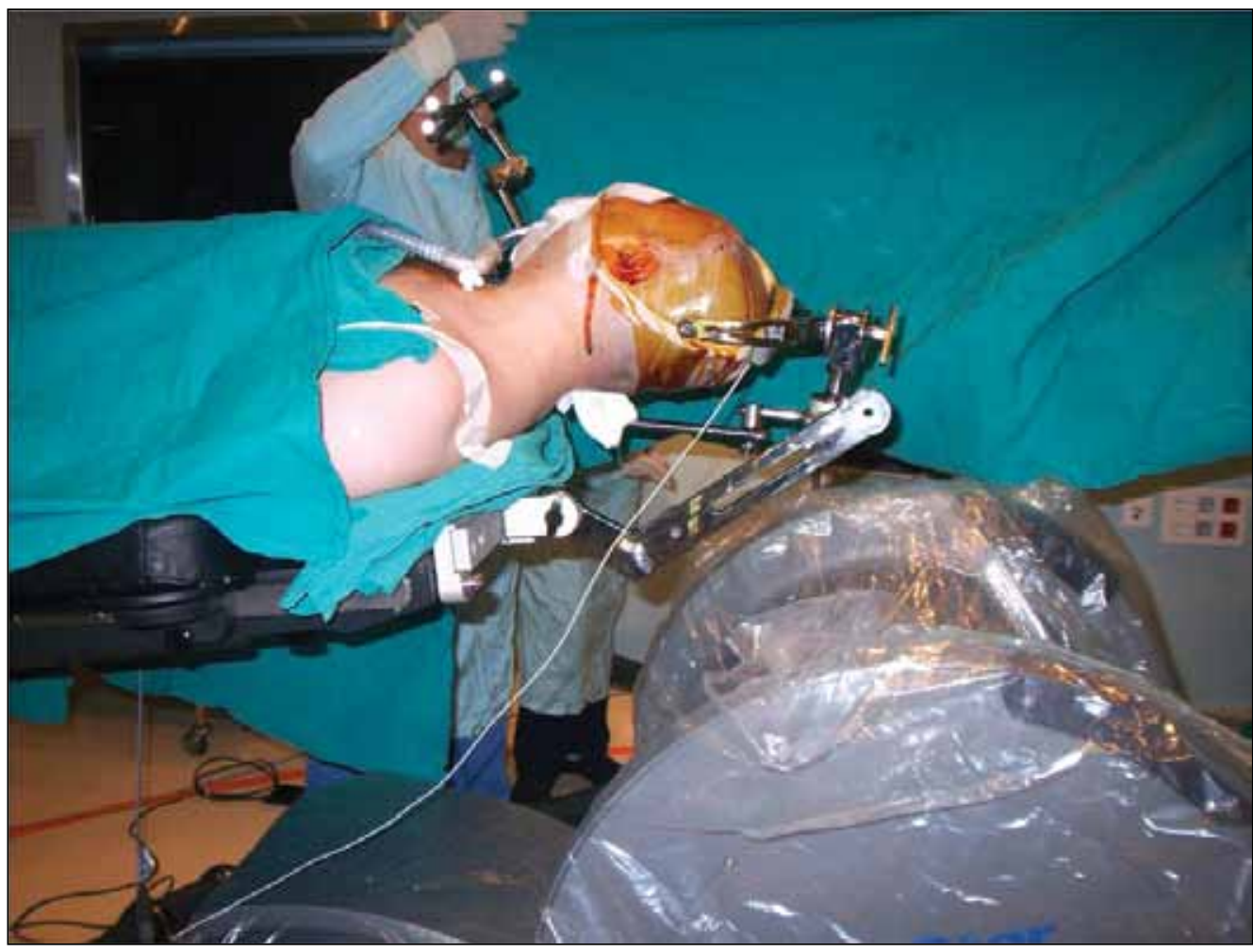

Figure 1: Preoperative set-up of the imaging and navigation system for a transcranial approach to the orbit are shown in this picture. Intraoperative MRI was placed below the patient's head and first MRI scan was obtained before surgery. MRIcompatible head holder and navigation frame were used for this patient. 
partial excision in one patient. The level of excision was determined by the impression of the surgeon associated with early postoperative CT and MRI of the patient obtained at the postoperative third month.

Totally removed tumors were cavernoma, metastasis (Figure $2 A-D$ ), epidermoid cyst (Figure 3 ), eosinophilic granuloma (Figure $4 A, B$ ) and fibroma. All of these were well-circumscribed and encapsulated, and there was no adhesion between the tumor and neurovascular structures. Gross total excision was achieved in 2 patients who had an epidermoid cyst. These tumors were encapsulated and very adherent to the adjacent structures. The tumor capsules were therefore left in place in order to avoid additional deficits. Subtotal excision was achieved in 9 cases. These cases were meningioma, osteoma (Figure 5), mesenchymal tumor, lymphangioma, lymphoma, mucocele and lipoma. The causes of subtotal excision were adhesion to neurovascular structures, firm characteristic of the tumor capsule, and difficult to dissect tumor capsule. Partial excision was performed only in one case who had optic nerve meningioma. The cause of partial removal was excessive bleeding during the surgery.

MRI-based neuronavigation was used in 16 patients and CTbased navigation was used in one patient. The histological diagnosis of the patient in whom $\mathrm{iCT}$ and CT-based navigation system was used was osteoma. This tumor had originated from the medial wall of the orbit and invaded both orbit and frontonasal regions. Subtotal excision was performed in this patient in order to not damage the whole medial wall of the orbit and not create a frontobasal bone defect in the skull base. In addition, the osteoma was too firm and has a benign nature. Subtotal removal was therefore performed and the patient is still under follow-up without any recurrence.

iMRI associated with neuronavigation was used in 3 patients. Total excision was performed in 2 patients and gross total excision in one patient. Histological diagnosis was epidermoid cyst and fibroma in 2 patients with total removal and epidermoid cyst in 1 patient who underwent gross total excision.

\section{DISCUSSION}

Advanced technological equipments were used in 17 patients with orbital tumors in a period of 5 years and safe and effective surgery was achieved without mortality and significant morbidity in our series. Usage of iMRI, iCT and neuronavigation systems may prolong the time of the surgical procedure but seem to provide better safety and effectiveness compared to standard endoscopic or microscopic approachesfor orbital tumors.

The knowledge of the anatomy of orbit and periorbital region is important in order to better understand the lesions of this region and to perform safe and effective surgical treatment of these lesions (2). Good anatomical knowledge facilitates surgical procedures to the orbit and decreases the mortality and morbidity after the surgery. The complex anatomical structure of the orbital region makes the surgical approach to the orbit difficult. Good anatomical knowledge associated with surgical experience is needed for a safe and effective surgery to the orbit.

The orbit contains the bulbus oculi, periorbita, and extraocular muscles associated with important neurovascular structures. It is in close relationship with the anterior and middle fossa and paranasal sinuses $(13,21)$. The orbit is like a cone or four-sided pyramidal cavity. It has 4 margins anteriorly and 3 margins posteriorly. The volume is about $30 \mathrm{ml}$. The medial walls are $45-50 \mathrm{~mm}$, the lateral walls are $40 \mathrm{~mm}(13,16,28)$. These walls are important for surgical approaches to the lesions of the orbit. The medial wall may facilitate orbital surgery because it is longer than the lateral wall. However, both approaches have their own advantages and disadvantages. Moreover, the knowledge of the size and shape of orbital walls is important especially for the orbital reconstructions.

Many traumatic, neoplastic or non-neoplastic lesions may occur in the orbit due to its complex anatomical structure. Primary or metastatic tumors may be seen in this region as in the other parts of the human body $(24,25)$. These tumors may cause cosmetic problems, limitation of eye movements, visual loss, or life-threatening conditions according to the location and nature of the tumor (1). Tumors that lie in the anterior or middle fossa not only cause visual symptoms but also neurological deficits secondary to the location site. For example, tumors invading the cavernous sinus may cause $3^{\text {rd }}, 4^{\text {th }}$, and $6^{\text {th }}$ nerve palsies, while tumors extending to the temporal lobe and middle fossa cause seizures, increased intracranial pressure and visual field defects. In addition, tumors invading the pituitary region cause hormonal disorders.

Bonavolonta et al. (1) performed a study on 2480 patients who had orbital lesions between 1976 and 2011. This is one of the largest series in the literature and they showed that dermoid cysts were the most common lesion of the orbit, followed by non-Hodgkin lymphoma, cavernoma, lymphangioma, mucocele, sphenoorbital meningioma and optic nerve meningiomas. Ohtsuka et al (20) retrospectively analyzed 244 patients who had a diagnosis of orbital tumor in a 21-year period. The most frequent tumors in this series were lymphoma, reactive lymphoid hyperplasia, pleomorphic adenoma, cavernoma and dermoid cyst. Interestingly, this study showed that orbital tumors were frequently observed in the 0-9 and 60-69 years age groups. Demirci et al. (6) performed a retrospective study in 200 patients who were older than 60 years and who had orbital tumors. In this series, the most frequent tumor was lymphoma and made up $24 \%$ of all tumors. Others were idiopathic orbital inflammation, cavernoma, optic nerve meningioma and sphenoorbital meningioma. Koopman et al. (14) analyzed 3640 cases between 1986 and 2006 to show the incidence of primary malignant orbital tumors. In this series, the most frequent tumors were lymphoma (67\%), rhabdomyosarcoma (12\%), adenocarcinoma (6\%) and adenoid cystic carcinoma (5\%). These tumors were frequently seen in the 0-15 and 60-80 

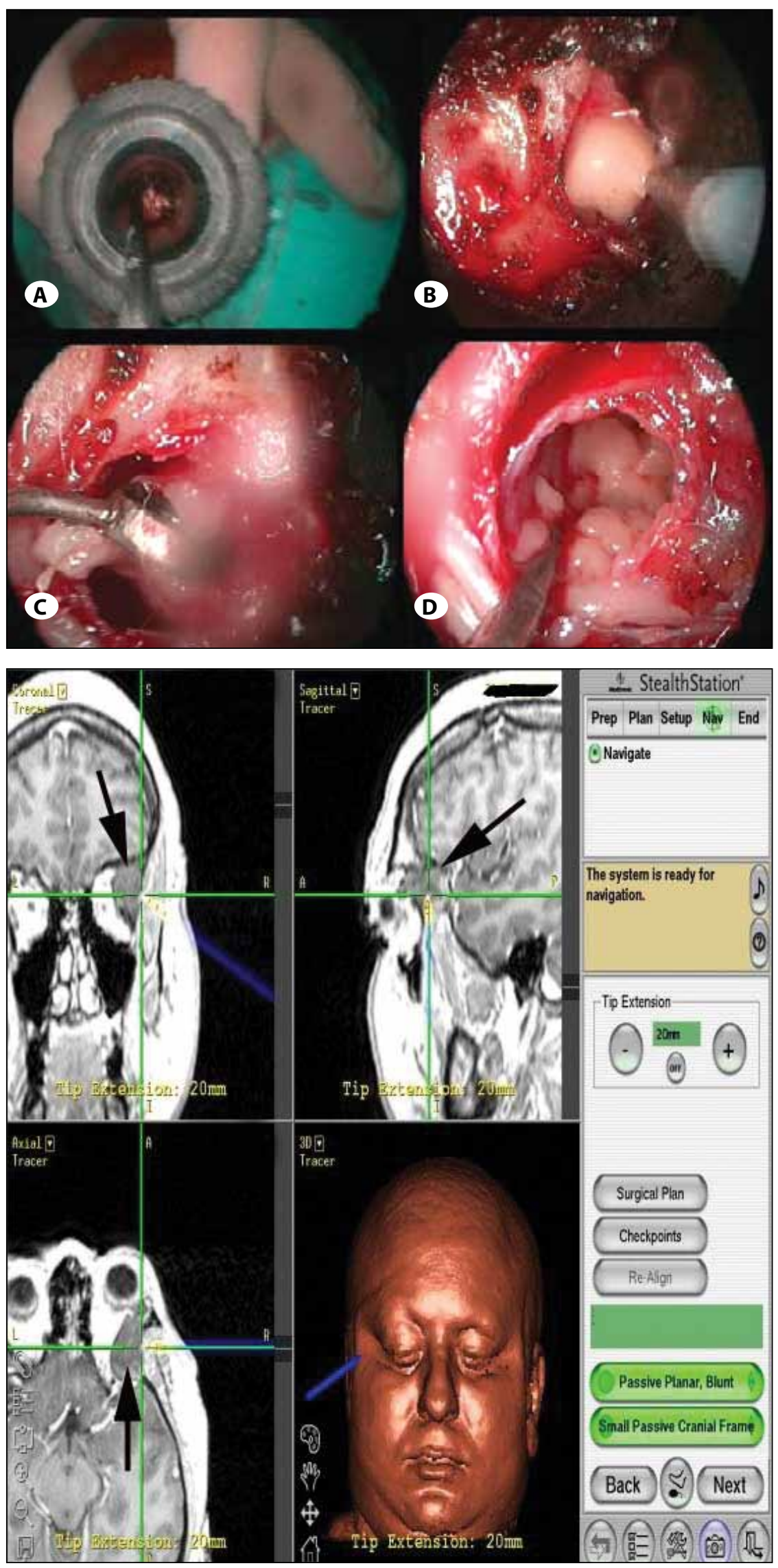

Figure 2: Metastasis of a pleomorphic adenoma which was located on the lateral wall of the orbit was removed using endoscopic approach. Firstly, the thoracoport was inserted $(\mathbf{A})$, then the tumor capsule was opened (B). The tumor was removed under endoscopic vision using ring curettes and blunt instruments (C and D).
Figure 3: MRI-based navigation system was used in a patient with right lateral orbital tumor. Black arrow shows the tumor. The tumor was removed with lateral orbitotomy and endoscopic approach. The diagnosis was epidermoid cyst. 
years age groups. Although the number of patient is low in our series, the mean age was 41.6 years. The order frequency for the tumors was meningioma (23.5\%), epidermoid cyst (17.6\%), cavernoma (6\%), osteoma, mesenchymal tumor, metastasis, lymphangioma, fibroma, eosinophilic granuloma, lymphoma, lipoma, and mucocele. In our series, meningioma was the most frequent tumor. The cause of this difference is probably that our series only included patients who were referred to the neurosurgery department. Previous series were composed of patients who were referred to the ophthalmology clinics. Patients with orbital tumors are mostly admitted to the ophthalmology clinics with visual symptoms and are usually operated in these departments. Our series is composed of extrabulbar orbital tumors while the intrabulbar orbital tumors that were operated in the ophthalmology department were not included in this study.

The most common symptoms of orbital tumors are proptosis, pain, visual loss, ptosis and diplopia (6). The frequency of these symptoms varies in some clinical series, but all of them are reported in the literature. In our series, the most common symptom was proptosis (53\%), followed by pain (47\%), visual
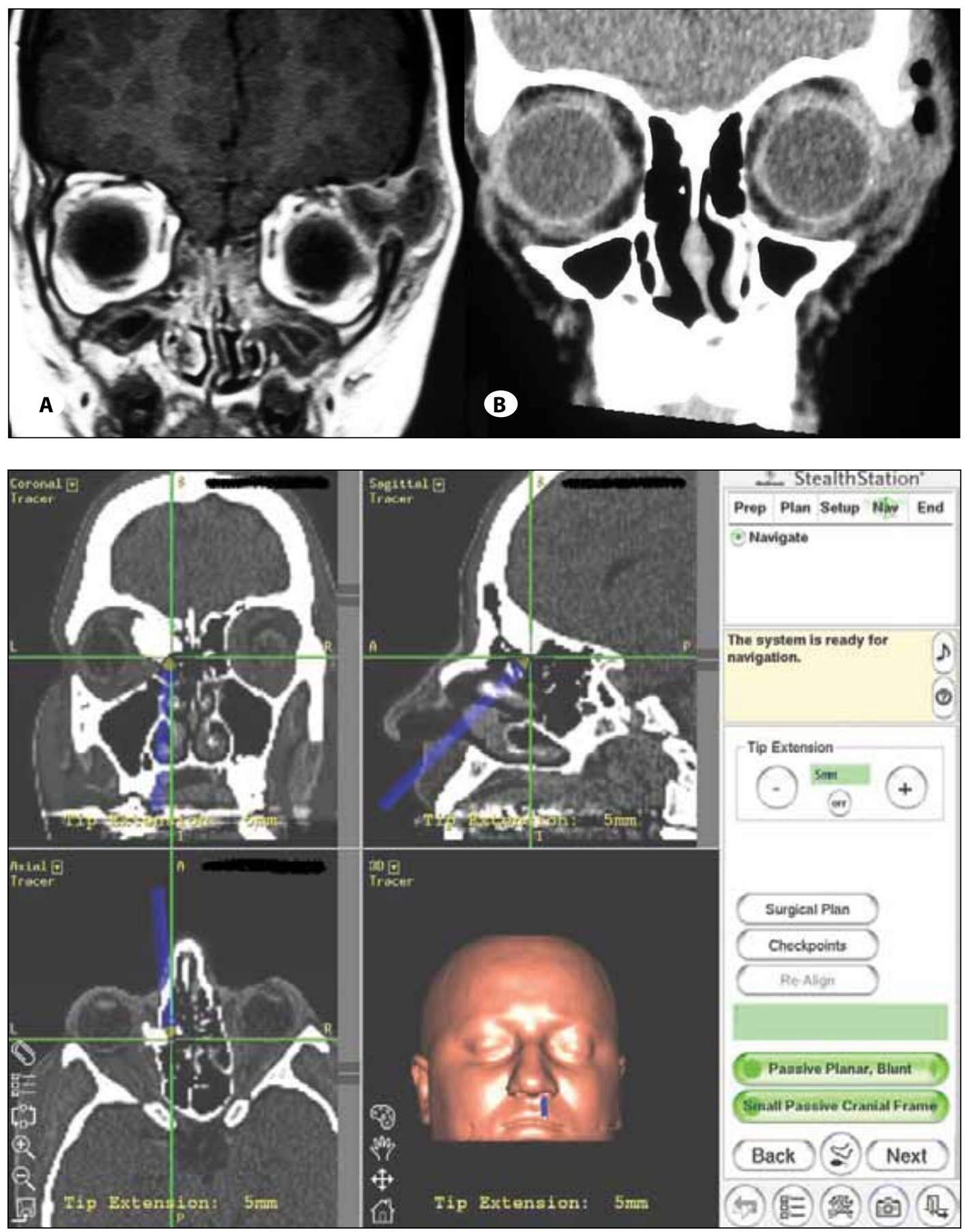

Figure 4: Left orbital eosinophilic granuloma was removed using microscopic lateral orbitotomy. The tumor was originated from the lateral wall of the orbit. A) Preoperative MRI scan of the patient shows left orbital tumor and B) Postoperative early CT scan of the patient shows the absence of the tumor.

Figure 5: CT-based navigation system was used for the removal of a left orbital medial wall osteoma. Endoscopic transnasal approach was used for the removal of this osteoma. 
loss, ptosis, and diplopia. The symptoms of our patients were the same as in the literature. There was no difference with the current literature $(1,20)$.

Intraoperative imaging techniques have been in use in neurosurgery since the 1970's. These techniques are ultrasound, CT and MRI. The first iCT was used in 1978 (27). This technique is especially used in spinal surgeries and functional neurosurgical procedures. It is possible to obtain 2-dimensional and 3-dimensional images by this technique. Gasinski et al. (8) used iCT in 125 cases who underwent spinal and functional neurosurgical procedures. Nemec et al (18) used a CT- and MRI-based navigation system in 10 patients who had orbital tumors. They emphasized the importance of this system on the orbital surgery. The use of ICT is more important than iMRI for solid tumors (osteoma and fibrous dysplasia) of the orbit. In our series, ICT was used in one patient who had an osteoma at the medial wall of the orbit. Preoperative radiological diagnosis of this lesion was a bone tumor. ICT was therefore used in this case and it showed the level of resection during the operation. Subtotal excision was performed in this case in order to protect the medial wall of the orbit and to prevent the occurrence of a large frontobasal defect.

iMRI was first used in Harvard University at 1994. This device continued to develop during the last 2 decades and 2 different iMRI systems are currently in use in neurosurgery. The first type is where the patient is fixed in the operating room and the $\mathrm{iMRI}$ moves for the intraoperative scanning. The second type is where the iMRI is fixed in a room and the patient moves to the iMRI during the surgery for scanning. Currently, intracranial tumors, especially glial tumors are the main indications for iMRI. However, iMRI may also be used in pituitary adenomas and other types of brain tumors. Kaya et al. (12) reported the use of low field iMRI in 6 pediatric patients with brain tumors and they showed that the use of iMRI was easier than in adults. In our study, we used low field iMRI in 3 patients with orbital tumors. Total excision was achieved in 2 patients and gross total resection in one patient.

iMRI provides detailed information about the location, size and nature of the orbital tumor and also contributes to the resection of tumor. As the volume of orbit is quite small, iMRI helps the surgeons to better visualize the surgical region. The navigation systems fail after the opening of periorbita due to protrusion of intraorbital fat and muscles. In these cases, iMRI provides real-time images of the tumor and orbit. These images are very helpful for the surgeon to reach the tumor safely. Moreover, the resection of cystic orbital tumors are always challenging for the surgeons whether the cyst is drained or not. iMRI also provides real-time and beneficial information about the cysts and cystic tumors. iMRI may also be used in solid tumors such as meningiomas and gliomas. Residual tumors may easily be detected by iMRI after debulking of solid tumors. Low-field iMRI has some advantages such as no patient movement and a relatively short scanning time compared to high-field iMRI. The risk infection is lower than for high-field iMRI. In our series, we used low-field mobile iMRI in 3 cases. No infection was observed in these cases. However, the quality of the images was not same as the high-field iMRI images.

The endoscopic technique has been in use in neurosurgery since the 1980's. During the first years, endoscopic surgery was used for intraventricular approaches and sellar lesions. However, it has also been used for orbital surgery in the last 10 years. The transnasal route is a minimal invasive way to reach the medial and inferomedial part of the orbit without a skin incision. With the endoscopic technique, surgical intervention is performed in a relatively small area with a 2-dimensional panoramic view. This technique requires a steep learning curve and longer experience than the other cranial procedures. The panoramic view and the view from different angles are advantages of the endoscopic approach. Development of 3-dimensional endoscopes and endoscopeholders enable double-handed surgery with more exposure of the deep-seated tumors $(3,17,26)$. Recently, Netuka et al. (19) used the endoscopic technique and iMRI for the removal of 3 orbital lesions that were located on the medial wall of the orbit. Two lesions were cavernomas and other was a solitary fibrous tumor. They advocated the endoscopic endonasal technique for lesions in the medial retrobulbar space and in the orbital apex medial to the optic nerve.

Song et al. (26) performed endoscopic surgery with neuronavigation in 19 patients with ethmoidal osteoma and they concluded that the endoscopic technique provides a safe and minimal invasive approach to the ethmoidal osteomas. Gazioğlu et al. (9) showed that the total resection of orbital cavernoma is possible through the endoscope and navigation system. In our series, we performed the endoscopic approach in 5 cases. The location of tumor was in the inferomedial in one case and medial in 4 cases. In addition to an endoscope, a navigation system was used in 5 cases while iMRI was used in 2 and iCT was used in one endoscopic case. We also emphasized that the endoscopic approach combined with intraoperative imaging techniques provides safe and effective surgery, especially for medial and inferolateral orbital lesions. $\mathrm{iCT}$ is of paramount importance to the navigation system in cases of orbital osteoma.

A neuronavigation system is very important for orbital surgeries. It came into use in the last 2 decades in orbital surgeries. In this system, preoperative $C T$ and MRI of the patient are obtained and uploaded to the computer before the beginning of surgery. The set-up of these images is performed in the operating room after fixation of the patient's head. The surgical strategy and approach are determined based on this system. Enchev et al. (7) reported 7 patients who underwent surgery for orbital tumor using a navigation system and they emphasized that this system does not replace anatomical knowledge but has a complementary role during surgery. Although the number of patients is very low in this series, this paper was very informative for the surgeons. The neuronavigation system is standard for all cranial and 
orbital surgeries in our department since 2008. CT-based navigation is useful for bone tumors such as osteoma and fibrous dysplasia while MRI-based navigation is important for soft tumors such as gliomas, lymphomas or metastasis. CT-angiography based navigation may be used in vascular lesions. Regarding orbital tumors, MRI-based navigation is useful especially for soft tumors until the opening of periorbita. Afterwards, intraorbital soft tissues protrude from the periorbita and preoperative MRI slices do not provide real-time information to the surgeon. Intraoperative imaging is therefore necessary after the opening of periorbita.

In conclusion, orbital tumors could be easily and safely removed using neuronavigation and intraoperative imaging systems. The appropriate navigation system and imaging method should be selected preoperatively by the surgeon. Currently, the set-up and use of a navigation system are very fast and comfortable for the patient and surgeon. However, this system becomes unreliable after opening of the periorbita due to protrusion of the orbital fat and muscles. Intraoperative imaging systems therefore help the surgeon after the periorbital opening. On the other hand, use of the endoscope is beneficial for removal of medial, inferomedial and lateral orbital tumors. Through this technique, the medial, inferomedial and lateral orbital lesions could be easily removed without a skin incision and cosmetic problems with a short hospital stay and healing period.

\section{REFERENCES}

1. Bonavolonta G, Strianese D, Grassi P, Comune C, Tranfa F, Uccello G, Iuliano A: An analysis of 2480 space-occupying lesions of the orbit from 1976 to 2011. Ophthal Plast Reconstr Surg 29:79-86, 2013

2. Burkat SN, Lemke BN: Anatomy of the orbit and its related structures. Otolaryngol Clin North Am 38: 825-856, 2005

3. Castelnuovo $P$, Battaglia $P$, Turri-Zanoni M, Volpi L, Bignami M, Dallan I: Transnasal skull base reconstruction using a 3-d endoscope: Our first impressions. J Neurol Surg B Skull Base 73: 85-89, 2012

4. Dandy WE: Results following the transcranial operative attack on orbital tumors. Arch Ophthalmol 25: 191-216, 1941

5. Davis FA: Primary tumors of the optic nerve. Arch Ophthalmol 23: 735-821, 1940

6. Demirci H, Shields CL, Shields JA, Honavar SG, Mercado GJ, Tovilla JC: Orbital tumors in the older adult population. Ophthalmology 109:243-248, 2002

7. Enchev Y, Tzekov C, Ferdinandov D, Cekov A, Spiriev T: Neuronavigation in cranioorbital neurosurgery-Do we really need it? Turk Neurosurg 21: 119-126, 2011

8. Gasinski P, Zielinski P, Harat M, Furtak J, Rakowska J, Paczkowski D: Application of intraoperative computed tomography in a neurosurgical operating theatre. Neurol Neurochir Pol 46: 536-541, 2012

9. Gazioglu N, Abuzayed B, Tanriover N: Neuronavigationguided endoscopic endonasal excision of an intraorbital intraconal cavernous hemangioma. J Craniofac Surg 22: 1802-1805, 2011
10. Izci $Y$, Gonul E: The microsurgical anatomy of the ciliary ganglion and its clinical importance in orbital traumas: An anatomic study. Minim Invasive Neurosurg 49: 156-160, 2006

11. Jackson IT, Marsh WR, Bite U: Craniofacial osteotomies to facilitate skull base tumor resection. Br J Plast Surg 39: 153-160, 1986

12. Kaya S, Deniz S, Duz B, Daneyemez M, Gonul E: Use of an ultralow field intraoperative MRI system for pediatric brain tumor cases: Initial experience with "PoleStar N20". Turk Neurosurg 22: 218-225, 2012

13. Kocabıyık N, Yalcın B, Kılıc C, Ozan H, Kırıcı Y: Morphological study on rectus muscles of eye. Gulhane Med J 46: 209-212, 2004

14. Koopman JH, van der Heiden-van der Loo M, van Dijk MR, Bijlsma WR: Incidence of primary malignant orbital tumours in the Netherlands. Eye (Lond) 25: 461-465, 2011

15. Kronlein RU: Zur pathologie und operativen behandlung der dermoid-zysten der orbita. Beitr z Klin Chir Tubing 4: 149-163, 1888

16. Lemke BN, Lucarelli MJ: Anatomy of ocular adnexa and orbit. In: Smith BC (ed), Ophthalmic plastic and reconstructive surgery. $2^{\text {nd }}$ ed. St. Louis (MO): CV Mosby, 1997: 3-78

17. Litynski GS: Endoscopic surgery: The history, the pioneers. World J Surg 23(8):745-753, 1999

18. Nemec SF, Peloschek P, Schmook MT, Krestan CR, Hauff W, Matula C, Czerny C: CT-MR image data fusion for computerassisted navigated surgery of orbital tumors. Eur J Radiol 73: 224-229, 2010

19. Netuka D, Masopust V, Belsan T, Profantova N, Benes V: Endoscopic endonasal resection of medial orbital lesions with intraoperative MRI. Acta Neurochir (Wien) 155:455-461, 2013

20. Ohtsuka K, Hashimoto M, Suzuki Y: A Rewiew of 244 orbital tumors in Japanese patients during a 21-years period: Origins and locations. Jpn J Ophthalmol 49: 49-55, 2005

21. Rene C: Update on orbital anatomy. Eye 20: 1119-1129, 2006

22. Rootman J, Stewart B, Goldberg RA: Principles of surgical management. Rootman J, Stewart B, Goldberg RA (eds), Orbital Surgery, A Conceptual Approach. New York: Lippincott-Raven, 1995:3-78

23. Seynaeve PC, Broos Jl: The history of tomography. J Belge Radiol 78(5):284-288, 1995

24. Shields JA: Diagnosis and management of orbital tumors. Philadelphia: WB Saunders, 1989:20-27

25. Shields JA, Shields CL: Atlas of orbital tumors. Philadelphia: Lippincott Williams \& Wilkins, 1999:187-224

26. Song XC, Chen LY, Zhang QQ, Sun $Y$, Wang $Q$, Zhang $H$, Chen $X M$, Wang Y: Endoscopic removal of ethmoid osteomas under navigation guidance. Zhonghua Er Bi Yan Hou Tou Jing Wai Ke Za Zhi 46(2):91-95, 2011

27. Steudel WI, Nabhan A, Shariat K: Intraoperative CT in spine surgery. Acta Neurochir Suppl 109:169-174, 2011

28. Whitnall SE: The anatomy of the human orbit and accessory organs of vision. New York: Oxford University Press, 1932: $1-252$ 